\title{
THERMAL ENERGY FROM BIOGAS GENERATED FROM CATTLE MANURE AND SEWAGE SLUDGE
}

Beatriz Costalonga Vargas

Rural Federal University of Rio de Janeiro (UFRRJ), Engineering Department, Campus Seropédica, ZIP Code 23890-000, Seropédica, RJ, Brazil

\section{Juliana Lobo Paes}

Rural Federal University of Rio de Janeiro (UFRRJ), Engineering Department, Campus Seropédica, ZIP Code 23890-000, Seropédica, RJ, Brazil

Corresponding author: juliana.lobop@yahoo.com.br

\section{Bernardo Marchon de Souza Antunes}

Rural Federal University of Rio de Janeiro (UFRRJ), Engineering Department, Campus Seropédica, ZIP Code 23890-000, Seropédica, RJ, Brazil

\section{João Paulo Barreto Cunha}

Rural Federal University of Rio de Janeiro (UFRRJ), Engineering Department, Campus Seropédica, ZIP Code 23890-000, Seropédica, RJ, Brazil

\section{Priscilla Tojado dos Santos}

Rural Federal University of Rio de Janeiro (UFRRJ), Engineering Department, Campus Seropédica, ZIP Code 23890-000, Seropédica, RJ, Brazil

\section{Ariane da Silva Bergossi}

Rural Federal University of Rio de Janeiro (UFRRJ), Engineering Department, Campus Seropédica, ZIP Code 23890-000, Seropédica, RJ, Brazil

\begin{abstract}
The major problems of public health, environmental impact, and energy dependence due to conventional fuels can be solved by using biogas from biodigesters. Therefore, the objective of this paper was to evaluate the energy potential of using biogas in the replacement of firewood and liquefied petroleum gas (LPG). For the biogas production, Indian model batch digesters were used in a batch supply system. Those were supplied with 100: 0, 75:25, 50:50, 25:75 and 0:100 sewage sludge: cattle manure (SS:CM). The calculation of the energy conversion was based on the accumulated biogas production, biogas production potential, the amount of waste produced by dairy cattle in a rural property and the equivalence of one cubic meter of gas with wood and LPG. In general, the adoption of biodigesters in rural properties to generate biogas for thermal energy consists of a viable and sustainable technology, regardless of the number of animals in the property. The use of sewage sludge antecipated biogas production, with the highest biogas production potential being $25: 75 \mathrm{SS}: \mathrm{CM}$. The financial savings obtained by the owner and / or community when installing a biodigester can be invested in the rural property. Therefore, it is concluded that there is a feasibility to replace firewood and LPG with biogas.
\end{abstract}

Index terms: Biodigester, anaerobic co-digestion, energetic conversion, firewood, liquefied petroleum gas.

Received: October, 30, 2019 - Accepted: January, 10, 2020

\section{INTRODUCTION}

Wood and its derivatives is the oldest source of fuel used to produce energy (Nascimento and Biaggioni, 2010). It is noteworthy that wood can be termed as firewood when used for energy purposes, and can serve as fuel in the processes of thermal, mechanical and electrical energy generation (Brito, 2007). Several factors may influence the use of wood as a fuel source; such as the country's level of development, availability of forests, environmental issues, and economic competition with other options of energy sources. In developing countries, wood is an essential fuel considered as a primary energy, mostly used for domestic purposes (Brito, 2007). 
However, the practice of cooking on wood stoves inside homes leads to damage to human health. The intoxication occurs due to the incomplete combustion of solid wood compounds, resulting in the release of toxic gases to health, besides polluting the home environment (Godoy, 2008). Among the problems related to human health, can be mentioned respiratory and cardiovascular diseases due to the emission of potentially toxic metals (Mengel and Kirkby, 2001).

Liquefied petroleum gas (LPG), known as cooking gas, consists of another conventional thermal energy source, that is formed by combining petroleum-derived butane and propane gases. Currently, the increase of the prices of LPG containers has been one of the main problems of its use in Brazil. However, firewood and LPG can be replaced as an energy source by the biomass of animal and human waste when it is packed in biodigesters. In the case of this hermetic reactor, the process of anaerobic codigestion occurs between two or more biomasses to produce biogas and biofertilizer (Bundhoo et al., 2016; Hagos et al., 2017). Biogas presents itself as a potential alternative to be used as a source of clean and renewable thermal energy (Cabbai et al., 2016).

Among the biomasses used in farm biodigesters, cattle manure can be highlighted due to its importance in the Brazilian agricultural scenario. In 2018, Brazilian production reached the record mark of 232.35 million livestock heads, which means an increase of $2.79 \%$ compared to 2017 (USDA, 2018). However, the process of anaerobic biodigestion in biodigesters with only bovine manure supply has a high departure phase to start biogas production (Orrico Junior et al., 2010; Matos et al., 2017; Paes et al., 2018). The time required to start biogas production in biodigesters for tributaries containing only cattle waste is around 4 to 5 weeks (Xavier et al., 2010; Matos et al. 2017). As a solution to this problem, it can be used as co-digestants to accelerate the degradation process of the substrate (Cabbai et al., 2016; Martínez et al., 2018). The sewage sludge is a codigestant that must be used with organic solid waste, such as animal waste, once it tends to accelerate the substrate digestion process due to the addition of nitrogen and stabilized microbial load (Cabbai et al., 2016).
From the perception that biogas can configure an efficient energy source, it is evident the need to know more in depth its potential in the substitution of conventional fuels. Thus, the objective of the present work was the energetic potential of using biogas in the replacement of firewoodand LPG.

\section{MATERIAL AND METHODS}

The experiment was carried out at Federal Rural University of Rio de Janeiro (UFRRJ), Seropedica - RJ campus, whose geographic coordinates are $22^{\circ} 45^{\prime} 48.74^{\prime \prime} \mathrm{S}$ and $43^{\circ} 41^{\prime}$ $19.01^{\prime \prime} \mathrm{W}$. The region's climate is classified as Aw according to Köppen classification and an average annual temperature of $24.5^{\circ} \mathrm{C}$ (Carvalho et al., 2006).

Sewage sludge from the Sewage Treatment Station (STS) and manure collected from Dairy Cattle Sector of UFRRJ were used as affluent. The sewage sludge was collected after the primary decanters of the STS and transferred in plastic containers to the Laboratory of Rural Electrification and Alternative Energies. Cattle manures were collected by scraping with mason shovel, avoiding the removal of foreign materials (soil, pasture, and stone). It emphasizes dairy cattle under conventional production system in UFRRJ, in which the animals were fed Tanzania grass (Panicum maximum) with corn, soybean meal and wheat meal.

In the experiment, Indian model benchtop biodigesters were filled with $1.7 \mathrm{~kg}$ of affluent containing 100:0, 75:25, 50:50, 25:75, 0:100 sewage sludge:cattle manure (SS:CM). The supply system was carried out discontinuous, that is, the affluent was conditioned in the biodigester only at the beginning of the experiment. The supply of the biodigesters with the affluent occurred $24 \mathrm{~h}$ after its collection, to avoid loss of biogas generated due to the early fermentative process. The hydraulic retention time (HRT) was 82 days (12 weeks). The average ambient temperature was $27.3^{\circ} \mathrm{C}$.

The biodigestor used in the experiment, consisting of a "water seal" containment chamber, fermentation chamber, gasometer and U-tube manometer of water column, as described by Matos et al. (2017). The biodigesters were 
placed on a bench top, under room conditions, sheltered from sunlight and rain.

The volume of biogas produced was determined by the product of the vertical displacement of the gasometer by its internal cross-sectional area during HRT. The biogas volume correction for the conditions of $1 \mathrm{~atm}$ and $20{ }^{\circ} \mathrm{C}$ was carried out based on the work done by Matos et al. (2017), which used the expression resulting from the combination of the laws of Boyle and Gay-Lussac (Equation 1).

$\frac{\mathrm{V} 0 \times \mathrm{P} 0}{\mathrm{~T} 0}=\frac{\mathrm{V} 1 \times \mathrm{P} 1}{\mathrm{~T} 1}$

where $\mathrm{V}_{0}$ corrected volume of biogas $\left(\mathrm{m}^{3}\right), \mathrm{P}_{0}$ biogas corrected pressure $(101.16 \mathrm{kPa}), \mathrm{T}_{0}$ biogas corrected temperature $(298.15 \mathrm{~K}), \mathrm{V}_{1}$ volume of gas in the gasometer $\left(\mathrm{m}^{3}\right), \mathrm{P}_{1}$ biogas pressure in the gasometer $(\mathrm{kPa}), \mathrm{T}_{1}$ biogas temperature in the gasometer $(\mathrm{K})$.

$\mathrm{P}_{1}$ was obtained by the sum between the atmospheric pressure of Seropédica $(100.85 \mathrm{kPa})$ and mean pressure checked in manometers $(\mathrm{kPa})$. Considering the parameters $\mathrm{T}_{0}$ and $\mathrm{P}_{0}$ constants, we obtained, Equation 2 for the correction of the biogas volume.

$V 0=\frac{P_{1} \times V 1}{T 1} \times 28,88$

The biogas production potential was calculated using the accumulated production and the affluent amount in the biodigesters. The value was expressed in $\mathrm{L}$ of biogas per $\mathrm{kg}$ of the affluent. The calculation of the energy production was based on the highest biogas production potential $\left(\mathrm{m}^{3} \mathrm{~kg}^{-1}\right)$ among SS:CM ratio, affluent amount (waste produced by rural cattle and sewage sludge) and the equivalent cubic meter of gas with firewoodand LPG. For the number of wastes, 20, 40, 60, 80 and 100 dairy cattle with waste production of 15 $\mathrm{kg}$ (animal day) $)^{-1}$ (Barrera, 1993) were used. Equation 3 calculated the biogas production generated for different quantities of animals in the herd.

$\mathrm{BP}=\mathrm{PBP} \times \mathrm{AA}$ where BP Biogas Production $\left(\mathrm{m}^{3}\right)$, BPP Biogas Production Potential $\left(\mathrm{m}^{3} \mathrm{~kg}^{-1}\right)$, AA Affluent Amount (kg).

Equation 4 estimated the energy conversion. Therefore, it was adopted that a cubic meter of biogas corresponds (BEQ) to $1.536 \mathrm{~kg}$ for firewood (Barrera, 1993) and $1.430 \mathrm{~kg}$ for LPG (Nogueira, 1986).

$\mathrm{EC}=\mathrm{BP} \times \mathrm{BEQ}$

where EC Energy Conversion (kg), BEQ Biogas Equivalence $\left(\mathrm{kg} \mathrm{m}^{-3}\right)$.

For comparison purposes, it was considered that residential consumption of firewood for cooking food is equivalent to $10.54 \mathrm{~kg}$ per household with five people (Vale et al., 2003). The amount of biogas canister purchased annually and the financial return were calculated considering that each residence uses monthly one gas canister (13 $\mathrm{kg}$ ) (Esperancini et al., 2007), with an average price of R\$ 86.00 (ANP, 2018) or US\$21.03. The price expressed in US Dollar (US\$) was collected in October 2019, where US\$ $1.00=$ $\mathrm{R} \$ 4.09$ (BCB, 2019).

The experimental results of accumulated biogas production as a function of HRT were submitted to regression analysis using the $R$ statistical program. The graphs of accumulated and potential biogas production were made using the Sigma Plot 2001 software, version 7.0.

\section{RESULTS AND DISCUSSION}

Figure 1 shows the experimental curves of the accumulated biogas production as a function of the hydraulic retention time for the 100:0, 75:25, 50:50, 25:75, 0:100 SS:CM ratio.

In the experiment using only cattle manure, the accumulated production started in the seventh week. The accumulated production of the 100:0 SS:CM ratio was higher than in other ratio until the second week. From the third week on, the entire ration that used the anaerobic co-digestion presented greater accumulated production when compared to the mono-digestion. 


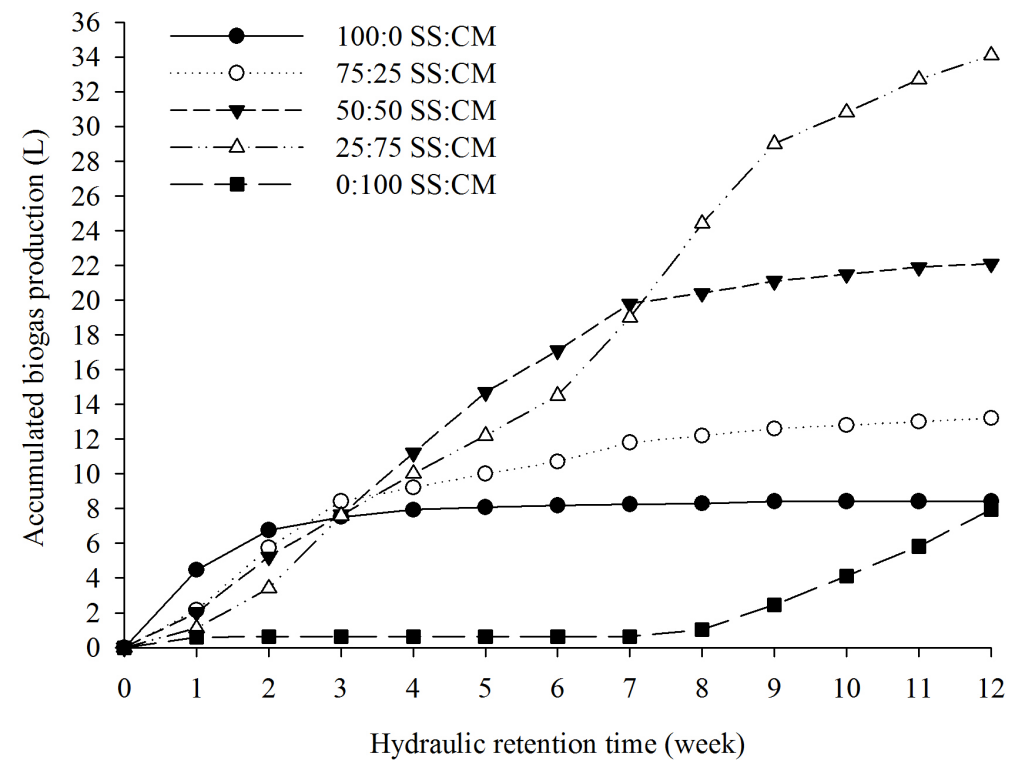

Figure 1: Accumulated biogas production (L) function of HRT (week).

This behavior can be explained by the slow adaptation between the different groups of microorganisms in the mixture and the anaerobic process, leading to an increase in the departure phase. The microbial load must initially adapt to each other and the environment, and then begin the process of organic matter degradation. This initial stage of stabilization is termed the lag phase of the growth of a natural population (Bordignon-Junior et al., 2011).

However, the accumulated production depends on the ratio and type of co-digester. In the present work, it is possible to observe a higher accumulated biogas production when adopting smaller ratio of sewage sludge. Nevertheless, higher ratio of sewage sludge result in higher initial accumulated biogas production. There is also a longer production time along the HRT for the ratios containing higher ratio of cattle manure (Figure 1), resulting in a higher supply of organic matter, which probably leads to increased biogas production and time of consumption of this matter by different stabilized microbial groups. The results obtained by Guerrero et al. (2016) for anaerobic co-digestion between sewage sludge and food residue corroborate the ones that were found in this paper. Luostarinen et al. (2009) when using sewage sludge and fat sludge from a meat processing industry obtained more stable productions for the anaerobic co-digestion treatments when compared to those with only sewage sludge.
The highest accumulated production occurred for the 25:75 SS:CM ratio, which can be confirmed by other authors. According to Parra-Orobio et al. (2016), the optimal condition for anaerobic co-digestion with sewage sludge is with $20 \%$ participation. Since this proportion provides better C / $\mathrm{N}$ ratio, lower complexity, lower installation costs, faster degradation of the organic load, lower lag phase, and higher biogas production, in contrast to the ratio of the largest shares of sewage sludge. Luna et al. (2009) connected the increase in biogas production, by adopting anaerobic co-digestion between urban solid waste $(80 \%)$ and sanitary sewage sludge $(20 \%)$, to the balance reached among the different groups of microorganisms who were responsible for the bio-stabilization process of the organic matter. On the other hand, Guerrero et al. (2016) reported that the proportion of 30:70 sewage sludge: food remainder presented a $32 \%$ higher biogas production than that obtained only with mono-digestion of sewage sludge. Table 1 shows the equations describing the behavior of accumulated biogas production during HRT, according to the regression analysis.

It can be verified that the accumulated biogas production as a function of HRT was represented by Response Linear Plateau, for the ratios 100:0, 75:25 and 50:50 SS:CM. Thus, the maximum cumulative production of 8.1907 , 12.60 and $21.40 \mathrm{~L}$ in the HRT of 2.32, 6.27 and 7.49 weeks, respectively, to 100:0, 75:25 and 50:50 
SS:CM. From this HRT, it was observed that the accumulated production remained stable due to the ceasing of biogas generation.

Differently, from the ratios mentioned above, the linear model represented 25:75 SS:CM indicates that the maximum cumulative biogas production was not reached over 12 weeks. In this HRT the accumulated biogas production was $35.69 \mathrm{~L}$. As for the anaerobic mono-digestion of the cattle manure, the long initial departure phase followed by biogas production resulted in the best adjustment of the experimental data to the exponential model with an $\mathrm{r}^{2}$ of 0.97 . For this ratio, after reaching 12 weeks the accumulated biogas production was $7.98 \mathrm{~L}$.

There is a higher accumulated biogas production for the ratios containing sewage sludge when compared to 100:0 and 0:100 SS:CM (Table 1). These results disagree with Méndez et al. (2017), who obtained higher production of biogas for the treatment using only animal waste in contrast to treatments with anaerobic co-digestion employing sewage sludge. The result of the authors mentioned above for treatment with only manure was $43.84 \mathrm{~L}$ of biogas, production $8.37 \mathrm{~L}$ greater than the relation with co-digester.

As expected, through the accumulated production results (Table 1 ), the anaerobic codigestion process resulted in higher energy potential (Figure 2). The biogas production potential in descending order was, respectively, $20.99 \mathrm{~L} \mathrm{~kg}^{-1}$ for $25: 75 ; 12.59 \mathrm{~L} \mathrm{~kg}^{-1}$ for $50: 50 ; 7.41 \mathrm{~L}$ $\mathrm{kg}^{-1}$ for $75: 25$; $4.82 \mathrm{~L} \mathrm{~kg}^{-1}$ for 100:0 and $4.80 \mathrm{~L} \mathrm{~kg}^{-1}$ for 0:100 SS:CM.
The efficiency of this process is confirmed by comparing the energy potential obtained through the anaerobic co-digestion of 25:75 SS:CM $\left(20.99 \mathrm{~L} \mathrm{~kg}^{-1}\right)$ to the results from other works. The anaerobic co-digestion between solid wastes and sewage sludge presented an energy potential of $5.6 \mathrm{~L} \mathrm{~kg}^{-1}$ (Luna et al., 2009). Results obtained by Matos et al. (2017) showed that the anaerobic bio-digestion of cattle manure had an energy potential of $0.20 \mathrm{~L} \mathrm{~kg}^{-1}$. Paes et al. (2018), when evaluating the anaerobic co-digestion between bovine and swine manure, obtained $0.015 \mathrm{~m}^{3} \mathrm{~kg}^{-1}$ to $4: 1$ bovine and swine manure. In the works mentioned above, to increase the efficiency of the process, water must be added to animal manure. However, with the results given, it can be inferred that it is unnecessary to add water when using sewage sludge in the anaerobic co-digestion with bovine waste. In environmental terms, great progress has been made in eliminating the use of water and the correct allocation of these environmental liabilities.

In face of a higher potential for biogas production the calculation was made by adopting the ratio 25:75 SS:CM and affluent amount (SS and $\mathrm{CM}$ ), as shown in Table 2.

Thus, the replacement of firewood by biogas could meet 3, 7, 10, 14 and 17 households, respectively, for properties with $20,40,60,80$ and 100 animals. Also in this context, the adoption of biogas in rural properties replaces burning of 37 , $74,111,147$ and $184 \mathrm{~kg}$ of firewood for thermal energy generation, respectively, for property with 20, 40, 60, 80 and 100 animals.

Table 1: Regression equations adjusted to the accumulated biogas production data during the anaerobic co-digestion process and respective determination coefficients.

\begin{tabular}{cccc}
\hline Ratio SS:CM & Interval & Equation & Coefficients of determination $\left(\mathrm{r}^{2}\right)$ \\
\hline \multirow{2}{*}{$100: 0$} & $\mathrm{X}_{\mathrm{i}}<2.32$ & $\hat{\mathrm{y}}=8.1907+3.3792 \mathrm{X}_{\mathrm{i}}$ & 0.97 \\
& $2.32 \leq \mathrm{X}_{\mathrm{i}} \leq 12$ & $\hat{\mathrm{y}}=8.1907$ & 0.94 \\
$75: 25$ & $\mathrm{X}_{\mathrm{i}}<6.27$ & $\hat{\mathrm{y}}=12.60+1.8311 \mathrm{X}_{\mathrm{i}}$ & 0.99 \\
& $6.27 \leq \mathrm{X}_{\mathrm{i}} \leq 12$ & $\hat{\mathrm{y}}=12.60$ & 0.98 \\
$50: 50$ & $\mathrm{X}_{\mathrm{i}}<7.49$ & $\hat{\mathrm{y}}=21.40+2.9285 \mathrm{X}_{\mathrm{i}}$ & 0.97 \\
$25: 75$ & $7.49 \leq \mathrm{X}_{\mathrm{i}} \leq 12$ & $\hat{\mathrm{y}}=21.40$ & $0.070 \mathrm{X}_{\mathrm{i}}$ \\
0
\end{tabular}

where $X_{i}$ hydraulic retention time (week), $\hat{y}$ accumulated biogas production (L). 


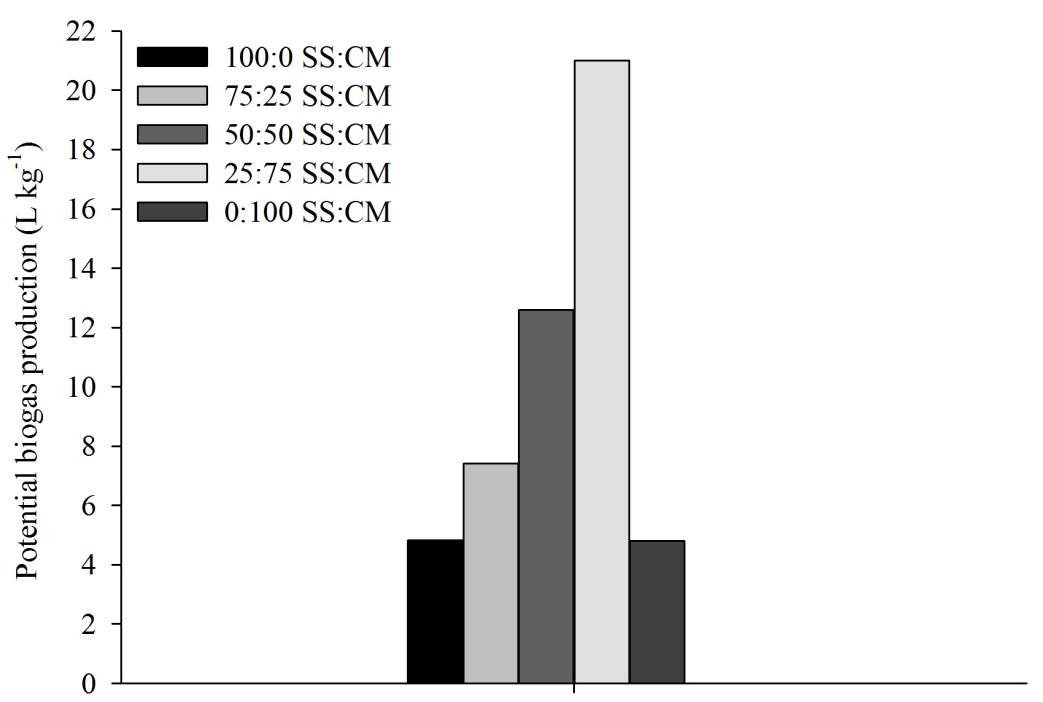

Figure 2: Potential biogas production L per kg of affluent.

Table 2: Biogas production of 25:75 SS:CM ratio for different animal quantities.

\begin{tabular}{|c|c|c|c|c|c|}
\hline \multirow{2}{*}{ Animals } & \multicolumn{3}{|c|}{ Affluents (kg) } & \multirow{2}{*}{$\begin{array}{l}\text { Biogas } \\
\text { production } \\
\qquad\left(\mathrm{m}^{3}\right)\end{array}$} & \multirow{2}{*}{$\begin{array}{c}\text { Energy } \\
\text { convertion } \\
\text { wood }(\mathrm{kg})\end{array}$} \\
\hline & SS & $\mathrm{CM}$ & Total & & \\
\hline 20 & 900 & 300 & 1200 & 24 & 37 \\
\hline 40 & 1800 & 600 & 2400 & 48 & 74 \\
\hline 60 & 2700 & 900 & 3600 & 72 & 111 \\
\hline 80 & 3600 & 1200 & 4800 & 96 & 147 \\
\hline 100 & 4500 & 1500 & 6000 & 120 & 184 \\
\hline
\end{tabular}

The importance of replacing firewood for biogas is proven, once it contributes to the reduction of public health problems related to the release of toxic gases originated from partial combustion. Considering that each household contains five people (Vale et al., 2003), the adoption of biodigesters for cooking will prevent 30 to 150 people from inhaling toxic gases inside their own houses. Besides that, it is important to address the reduction of environmental problems due to local deforestation to obtain solid fuel.

Apart from the firewood for cooking, in rural properties are also used the LPG marketed in a $13 \mathrm{~kg}$ can. In the present study, it can be achieved with the use of biodigesters in rural properties $34,69,103,137$ and $172 \mathrm{~kg}$ of LPG, respectively, for 20, 40, 60, 80 and 100 animals (Table 3).

Table 3 presented the amount of biogas canister purchased annually and the financial return.

Generating thermal energy in the same place of consumption entails in the energetic independence, given that often the residents of isolated communities and rural producers do not have access to energy due to the problematic logistics of fuel transportation.

Table 3: Biogas canister amount and financial return of biogas to replace LPG.

\begin{tabular}{cccc}
\hline Animals & $\begin{array}{c}\text { Energy } \\
\text { convertion LPG } \\
(\mathrm{kg})\end{array}$ & $\begin{array}{c}\text { Biogas } \\
\text { canister } \\
\text { (unit) }\end{array}$ & $\begin{array}{c}\text { Annual financial } \\
\text { return (US\$) }\end{array}$ \\
\hline 20 & 34 & 32 & 666.13 \\
40 & 69 & 63 & $1,332.26$ \\
60 & 103 & 95 & $1,998.40$ \\
80 & 137 & 127 & $2,664.53$ \\
\hline 100 & 172 & 158 & $3,330.66$ \\
\hline
\end{tabular}

In general, the adoption of biodigesters in rural properties to produce biogas as a thermal energy source consists of viable and sustainable technology. The savings obtained by the owner and/or community when installing a biodigester can be reversed for their property.

Likewise, for comparative purposes, the energy conversion of the 0:100 SS:CM ratio was made based on its energy potential $\left(0.0048 \mathrm{~m}^{3}\right.$ $\left.\mathrm{kg}^{-1}\right)$ and the maximum amount of effluent (6.0 $\mathrm{kg}$ ). According to the obtained data, the biogas production was $30 \mathrm{~m}^{3}$, which corresponds to $46 \mathrm{~kg}$ of firewood and $43 \mathrm{~kg}$ of LPG. Overall, it can be observed that, when compared to mono-digestion, sewage sludge and bovine waste supplied biodigesters in the $25: 75$ ratio is a promising option due to the increase of $75 \%$ 
in biogas production. Thus, confirming the beneficial effect in the process of anaerobic codigestion.

\section{CONCLUSIONS}

The 25:75 SS:CM ratio obtained the highest biogas production potential, without reaching the maximum cumulative production during 12 weeks. For this ratio, it is feasible to substitute firewood and LPG for biogas from bovine manure and sewage sludge generated in biodigesters.

\section{ACKNOWLEDGEMENTS}

The authors wish to thank (i) the Rural Federal University of Rio de Janeiro (UFRRJ) for providing office space and infrastructure to achieve this article, (ii) the FAPERJ for financial support.

\section{REFERENCES}

ANP - AGÊNCIA NACIONAL DO PETRÓLEO, GÁS NATURAL E BIOCOMBUSTÍVEIS. Sistema de levantamento de preços. Available in: (https:/ / preco. anp.gov.br/include/resumo_mensal_combustiveis. asp). Access in November 30, 2018.

BARRERA, P. Biodigestores - Energia, Fertilidade e Saneamento para Zona Rural. 1 ed. São Paulo: Ícone, 1993. 106p.

BCB - BANCO CENTRAL DO BRASIL. Dólar Americano. Available in: (https://www.bcb.gov.br/ acessoinformacao/legado?url=https:\%2F\%2Fwww4. bcb.gov.br\% $2 \mathrm{Fpec} \% 2 \mathrm{Ftaxas} \% 2 \mathrm{Fbatch} \% 2 \mathrm{Ftaxas}$. asp\%3Fid\%3Dtxdolar). Access in October 08, 2019.

BORDIGNON-JUNIOR, S. E. et al. Inibição do crescimento de bactérias Gram-negativas em microdiluição por tratamento com Nisina e EDTA. Journal of Biotechnology and Biodiversity, 3(4):127135, 2012.

BRITO, J. O. O uso energético da madeira. Estudos Avançados, 21(59):185-193, 2007.

BUNDHOO, Z. M. A. et al. Potential of biogas production from biomass and waste materials in the small island developing state of mauritius. Renewable and Sustainable Energy Reviews, 56:1087-1100, 2016.

CABBAI, V. et al. Pilot plant experience on anaerobic codigestion of source selected OFMSW and sewage sludge. Waste Management, 49:47-54, 2016.

CARVALHO, T. et al. Créditos de carbono e geração de energia com uso de biodigestores no tratamento de dejetos suínos. Revista Acadêmica Ciências Animal, 4(3):23-32, 2006.

ESPERANCINI, M. S. T. et al. Viabilidade técnica e econômica da substituição de fontes convencionais de energia por biogás em assentamento rural do Estado de São Paulo. Revista Engenharia Agrícola, 27(1):110-118, 2007.

GODOY, I. Fogão a lenha: um passatempo agradável, uma rotina perigosa. Jornal Brasileiro de Pneumologia, 34(9):637-638, 2008.

GUERRERO, J. et al. Evaluación de la co-digestión anaerobia de lodos de aguas residuales municipales con residuos de alimentos. Revista ION, 29(1):63-70, 2016.

HAGOS, K. et al. Anaerobic co-digestion process for biogas production: Progress, challenges and perspectives. Renewable and Sustainable Energy Reviews, 76:485-1496, 2016.

LUNA, M. L. D. et al. Tratamento anaeróbio de resíduos orgânicos com baixa concentração de sólidos. Revista Engenharia Agrícola, 29(1):113-121, 2009.

LUOSTARINEN, S. et al. Increased biogas production at wastewater treatment plants through co-digestion of sewage sludge with grease trap sludge from a meat processing plant. Bioresource Tecnologie, 100(1):79$85,2009$.

MARTÍNEZ, E. J. et al. Codigestion of sludge and citrus peel wastes: Evaluating the effect of biochar addition on microbial communities, Biochemical Engineering Journal, 137:314-325, 2018.

MATOS, C. F. et al. Biogas production from dairy cattle manure, under organic and conventional production systems. Revista Engenharia Agrícola, 37(6):1081-1090, 2017. 
MÉNDEZ, M. A. S. et al. Producción de biogás mediante codigestión anaerobia de excretas de borrego y rumen adicionadas con lodos procedentes de una planta de águas residuales. La Revista Internacional de Contaminación Ambiental, 33(1):109-116, 2017.

MENGEL, K. et al. Principles of plant nutrition. 5 ed. Dordrecht: Kluwer Academic Publishers, 2001. 849p.

NASCIMENTO, M. D.; BIAGGIONI, M. A. M. Avaliação energética do uso de lenha e cavaco de madeira para produção de energia em agroindústria Seropédica. Revista Energia na Agricultura, 25(3):104-117, 2010.

NOGUEIRA, L. A. H. Biodigestão e a Alternativa Energética. São Paulo: Editora Nobel, 1986. 93p.

ORRICO JÚNIOR, M. A. P. et al. Influência da relação volumoso: concentrado e do tempo de retenção hidráulica sob a biodigestão anaeróbia de dejetos de bovinos, Revista Engenharia Agrícola, 30(3):386-394, 2010 .

PAES, J. L. et al. Potencialidade do biogás gerado pela codigestão entre dejeto bovino e suíno. In: ABDALA, P. J. P. Energia Solar e Eólica. 1 ed. Ponta Grossa: Atena Editora, 2018. v. 2, p 317-332.

PARRA-OROBIO, B. A. et al. Influence of the mixing ratio on the anaerobic co-digestion of municipal biowaste with domestic wastewater sludge on methane production. Dyna, 83(199): 86-93, 2016.

USDA - US DEPARTMENTO F AGRICULTURE. Available in: (<http://www. farmnews.com.br/historias / maiores-rebanhosmundiais/>). Access in January 31, 2019.

VALE, A. T. et al. Estimativa do consumo residencial de lenha em uma pequena comunidade rural do Município de São João D'Aliança - GO. Ciência Florestal, 13(2):159-165, 2003.

XAVIER, C. A. N. et al. Parâmetros de dimensionamento para biodigestores batelada operados com dejetos de vacas leiteiras com e sem uso de inóculo. Revista Engenharia Agrícola, 30(2): 212-223, 2010. 